\title{
TAPHOFACIES AND BIOEVENTS IN MARINE SEQUENCES OF THE APPALACHIAN BASIN MIDDLE DEVONIAN
}

BRETT, Carlton E.*, Dept. of Geological Sciences, University of Rochester, Rochester, NY 14627 USA; BAIRD, Gordon C., Dept. of Geosciences, SUNY Fredonia, Fredonia, NY 14063 USA

The Middle Devonian (Givetian) Hamilton Group is composed of widespread, time-stratigraphic, discontinuity-bounded depositional cycles which correspond to sequences and sub-sequences. Not only do recurrent lithofacies and biofacies units correlate predictably with given parts of cycles, distinctive taphonomic features also correlate with appropriate parts of transgressive-, early highstand-, and late highstand (regressive) systems tracts within sequences. Transgressive systems tracts (TSTs) are marked by widespread, thin $(0.5$ to $3 \mathrm{~m})$, winnowed, shelly sandstones or skeletal wacke- to grainstones. Bases are typically heavily burrowed with a distinctive firmground ichnofacies. Internally, the beds display mixtures of variably disarticulated and corraded skeletal fragments, especially pelmatozoan debris. Condensed intervals are typified by sharp diastemic contacts between TSTs and overlying maximum highstand shales. These surfaces of maximum starvation may have thin (centimeters) lags of phosphatic, concretionary, or pyritic diaclasts, bones and conodonts as well as corroded carbonate skeletal debris. Early highstand deposits are characterized by an alternation of discrete storm beds with mudstones which may yield exceptionally well-preserved faunas. Late highstand- and regressive taphofacies display greater evidence of sediment-shell disturbance by bioturbation and repeated storms. The decrease in accomodation space dictates sediment-bypass and mixing with increased evidence of skeletal disarticulation and shell abrasion.

A recurring, and somewhat enigmatic phenomenon consists of widespread (to $100 \mathrm{~s}$ of $\mathrm{km}$ ) shell and reworked concretion layers, associated with diastems, which occur at the late highstand or early sea level-fall position within offshore, low energy mudstones. These "precursor beds" are sediment-starved lags, which mark abrupt shoaling events followed by a return to deeper-water deposits below the transition to lowstand conditions. These lags either represent the overprint of condensed smaller cycles superimposed on larger ones or they may record a fundamentally new, littleunderstood, process associated with abrupt sea level drop.

Most of the typical Givetian "Hamilton fauna" appears abruptly in the second major sub-sequence (4th order cycle) of the Hamilton Group. The Hamilton fauna was partitioned into distinctive biofacies which were remarkably stable in terms of taxonomic composition, guild structure and relative abundance. These biofacies tracked favored environments and recur through 10 or more basinwide cycles (including sub-sequences) during some 6-7 my. Surprisingly, relative lowstands, represented by sequence-bounding unconformities, appear to have had very little disruptive influence on tracking Hamilton biotas. Very few species became extinct, immigrated, or underwent significant morphological change during the entire Givetian interval. Instead, both the initiation and termination of the Hamilton fauna correspond with major deepening events (Marcellus and Genesee transgressions) of combined eustatic/tectonic origin. In both cases, the major faunal changes (extinctions, immigrations, species evolution) appear to be associated with widespread anoxic black shales in condensed early highstands of sequences. Both of these correspond to global bioevents (Kacak-otomari and Pharciceras events) that have been related to climatic change. This observation suggests that the major transgressions may have been associated with widespread environmental restructuring. 